\title{
HONG KONG'S EXERCISE OF EXTERNAL AUTONOMY: A MULTI-FACETED APPRAISAL
}

\section{By}

\section{Roda Mushkat*}

\section{Introduction}

Hong Kong had loomed large on the international legal agenda, albeit not necessarily in the institutional sense of the term, in the period leading to the resumption of sovereignty by the People's Republic of China (PRC) in 1997. Since then, academic and policy interest in its unique status has largely subsided. This may be attributed to the fact that the issue has formally been settled and the absence of effective mechanisms for monitoring and enforcement of compliance with the bilateral accord underpinning the new legal order. The marginalisation of the subject has arguably left an analytical vacuum as several dimensions of the post-1997 picture merit attention on the part of international lawyers. One topic that continues to be of both practical and theoretical importance -- the unconstrained pursuit, within the 'One Country, Two Systems framework, of key strategic goals in the external arena -- is addressed from logicallyinterrelated perspectives in this paper.

It should be noted at the outset that, from an international legal and constitutional standpoint, Hong Kong has emerged in 1997 from an extended period of colonial dependence, although of a mostly enlightened variety, not as an integral part of the Chinese body politic but as a highly autonomous entity empowered to pursue its domestic socio-economic agenda in a virtually unfettered fashion and to conduct selectively its external affairs without overt involvement by the central government in Beijing or any of its provincial arms. This ingenious structural configuration, allowing a quintessentially capitalist enclave to continue to function smoothly on the fringes of 'Communist' China

\footnotetext{
* Professor of Law, School of Social Sciences and Law, Brunel University, and Honorary Professor, Faculty of Law, University of Hong Kong. The author wishes to acknowledge the generous financial support provided by the University of Hong Kong Research Council and the capable research assistance of Suzette Lin. The usual disclaimers apply.
} 
following the removal of an effective Western democratic buffer, was enshrined in the Sino-British Joint Declaration (JD) and the Hong Kong Special Administrative Region (HKSAR) Basic Law (BL). ${ }^{1}$

In both documents, a formal distinction is drawn between 'foreign affairs relating to the HKSAR,' which are the preserve of the Central People's Government (CPG), and 'relevant external affairs,' which the HKSAR is authorized to manage in accordance with its policy goals, subject to the provisions of the BL. The distinction is not devoid of ambiguities. For example, the participation of representatives of the HKSAR as members of delegations of the Government of the People's Republic of China in negotiations at the diplomatic level directly affecting Hong Kong (BL 150) ${ }^{2}$ may legitimately be construed as amounting to engagement in foreign affairs. Such ambiguities notwithstanding, however, the wide scope for manoeuvre in the external arena is not in doubt.

Notably, the HKSAR may on its own, using the name 'Hong Kong, China,' maintain and develop relations, and conclude and implement agreements, with foreign states, regional associations and established international organisations in appropriate strategic areas, including the economic, trade, financial and monetary, shipping, communications, tourism, cultural and sports domains (BL 151). This freedom of action is further enhanced due to the availability of official channels, normally open just to states, to promote Hong Kong interests through key international organisations by virtue of incorporation into the national delegation (BL 152). The institutional platforms which can be productively accessed on that basis encompass, among others, the International Civil Aviation Organisation (ICAO), International Labour Organisation (ILO), International Monetary Fund (IMF), International Maritime Organisation (IMO), International

\footnotetext{
${ }^{1}$ See generally: Yash P. Ghai, Hong Kong's New Constitutional Order: the Resumption of Chinese Sovereignty and the Basic Law, $2^{\text {nd }}$ ed. (Hong Kong: Hong Kong University Press, 1999); Roda Mushkat, One Country, Two International Legal Personalities: The Case of Hong Kong (Hong Kong: Hong Kong University Press, 1997)

${ }^{2}$ Note a telling remark by the former Commissioner of the Chinese Foreign Ministry in Hong Kong, Ma Yuzhen: "Permitting foreign nationals to take part in international conferences as members of a government delegation is something not only unprecedented in the diplomatic history of New China but also rare in the history of international diplomacy. Cited in 'Pledging to Ensure Success of SAR' China Daily (Hong Kong edition), 23 December 1997.
} 
Telecommunications Union (IUT), Universal Postal Union (UPU), World Bank (WB), World Health Organisation (WHO), World Intellectual Property Organisation (WIPO) and World Tourism Organisation. ${ }^{3}$

For international organisations that can admit actors other than states, the HKSAR may participate in its own capacity under the name 'Hong Kong, China' (BL 152). This offers entry, inter alia, into economically and technically (indeed, even politically) important bodies such the Asian Development Bank (ABD), Asia-Pacific Economic Cooperation (APEC), Bank for International Settlements (BIS), Financial Stability Forum (FSF), International Association of Insurance Supervisors (IAIS), United Nations Environment Programme (UNEP-INFOTERRA), International Textiles and Clothing Bureau (ITCB), World Customs Union (WCU), World Meteorological Association (WMO) and World Trade Organisation (WTO). ${ }^{4}$ PRC membership is not an impediment because the CPG is committed to facilitating Hong Kong's presence (BL 152) and ensuring that the international organisations involved maintain offices in the territory on quasi-diplomatic terms (BL 157).

As a thriving commercial and financial centre, and a vibrant communications and logistics/transportation hub, which performs a vital regional and global role, Hong Kong conducts its external affairs through non-governmental institutional vehicles as well as their governmental counterparts. This manifests itself in the domestic arena, where various independent entities (e.g., the Asia Business Council, Asia Society, Better Hong Kong Foundation, Civic Exchange, country-specific chambers of commerce, Hong Kong Council of Social Services, local universities, Oxfam, Pacific Economic Cooperation Council/PECC and Vision 2047) ${ }^{5}$ devote substantial resources to advancing the

\footnotetext{
${ }^{3}$ For a list of the international organisations limited to states in which representatives of the HKSAR government participate, in accordance with BL 152, as members of delegations of the PRC, or in such other capacity as may be permitted by the CPG and the international organisation concerned, see: http://www.info.gov.hk/cab/topical/iorg_Its.html.

${ }^{4}$ For a list of intergovernmental organisations not limited to states in which the HKSAR participates using the name 'Hong Kong, China,' see: http://www.info.gov.hk/cab/topical/iorg gov.html.

${ }^{5}$ See generally: 'Study on the Third Sector Landscape in Hong Kong,' released by the Central Policy Unit (CPU), HKSAR Government on 27 August 2004, available online at http://www.info.gov.hk/cpu/english/papers/3rd_content.pdf.
} 
territory's image abroad and building networks spanning the Eastern and Western hemispheres. It is thus reassuring that Hong Kong may forge its own relationships with non-governmental international organisations in fields such as the arts, culture, education, infrastructure, labour, the professions, religion, science, social welfare and technology. Typical examples include the Airports Council International (ACI), Association of Asia Pacific Performing Arts Centres (AAPPAC), Association of Science-Technology Centres (ASTC), International Accreditation Forum (IAF), International Bar Association (IBA), International Federation on Ageing (IFA), International Organisation for Standardisation (ISO) and International Society for Quality in Health Care. ${ }^{6}$

Hong Kong's external relations platform is augmented by an extensive international treaty regime applicable to the HKSAR (under BL 153), which gives rise to a broad spectrum of international responsibilities. Over two hundred multilateral treaties are in force in the territory, covering a wide range of subjects such as civil aviation, conservation, customs, human rights, intellectual property, international labour conventions, merchant shipping, outer space, telecommunications and transportation. ${ }^{7}$ Several of these treaties do not extend to mainland China. The HKSAR is party to more than 130 bilateral agreements with 60 countries concerning strategic fields of economic activity, most pertinently air services, double taxation avoidance and investment promotion and protection. ${ }^{8}$ Significantly, the HKSAR government, 'duly authorized by the Sovereign Government,' has concluded a large number of Mutual Legal Assistance Agreements, Transfer of Sentenced Persons Agreements and Surrender of Fugitive Offenders Agreements, customarily regarded as a matter of high statecraft. In a similar vein, visa abolition agreements, commonly signed by diplomatic or foreign affairs representatives, have been entered into by the HKSAR under BL $155 .{ }^{9}$

\footnotetext{
${ }^{6}$ For a list of the non-intergovernmental organisations of which HKSAR is a member, see: http://www.info.gov.hk/cab/topical/bottom4.htm.

${ }^{7}$ For a list of multilateral treaties in force and applicable to the HKSAR, see: http://www.legislation.gov.hk/interlaw.htm.

${ }^{8}$ For links to lists of bilateral international agreements of the HKSAR which have come into force, see: http://www.legislation.gov.hk/choice.htm.

${ }^{9}$ See: http://www.legislation.gov.hk/choice.htm.
} 
This multi-layered structure is underpinned by an institutional network designed to ensure effective voice and action in major international centres, at least with respect to economic and trade-related issues. While Hong Kong may accommodate foreign consular missions and the semi-official presence of foreign state representatives, and does so on a distinctly large scale,$^{10}$ it is somewhat constrained in pursuing its interests globally because it does not enjoy a sovereign status and hence lacks a proper diplomatic machinery. To circumvent these constraints, the HKSAR may establish its own economic and trade missions abroad (BL 156) and has proceeded to do so in a determined manner, albeit one reflecting changing circumstances and shifting priorities. ${ }^{11}$

Chinese good will and support are essential elements in the equation, but a policy configuration with such wide ramifications cannot be sustained in an international vacuum. It is thus important to note that Hong Kong's position as a focal point for commerce, communications, finance, logistics and transportation in Asia-Pacific and beyond is universally acknowledged. For example, the territory's disciplined strategy of 'positive non-intervention' has prompted the Heritage Foundation to place it consistently at the top of its Index of Economic Freedom since 1997. ${ }^{12}$ By the same token, the International Institute for Management Development's (IMD) annual survey, which assesses overall economic performance, public sector efficiency, private sector dynamism and robustness of infrastructure, has invariably ranked Hong Kong as one of the most competitive countries/territories in the world. ${ }^{13}$

From the political perspective, which poses greater challenges, legitimacy has been conferred on the HKSAR by governments with different orientations across the globe, including those with considerable international capabilities and ones espousing liberal-

\footnotetext{
${ }^{10}$ As at 21.7.2005, there are 56 Consulates-General, 54 Honorary Consulates and 5 Officially Recognised Bodies in Hong Kong. See: http://www.info.gov.hk/protocol/consular/

${ }^{11}$ At present there are Hong Kong Economic and Trade Offices (ETOs) in countries that are major trading partners of the HKSAR, namely: Australia, Belgium (the EU), Canada, Japan, Singapore, Switzerland, the UK and the US. See links to the individual ETOs at http://en.wikipedia.org/wiki/Hong_Kong_Economic and_Trade_Office.

${ }^{12}$ See most recent ranking in '2004 Index of Economic Freedom' at http://cf.heritage.org/index2004test/country2.cfm?id=HongKong.

${ }^{13}$ See most recent ranking in 'The World Competitiveness Scoreboard 2005' at http://www01.imd.ch/wcc/ranking/
} 
democratic values. The positive attitude displayed has manifested itself both at the general level and with respect to the potentially problematic 'One Country, Two Systems' framework. Post-1997 reports on Hong Kong by the American and British governments, as well as the European Union, have struck a favourable tone overall. ${ }^{14}$ An equally reassuring evaluation of Hong Kong's political record has been offered by independent analysts. Political and Economic Risk Consultancy has thus placed the territory in the same category as the United States and Australia, and ahead of the rest of the region, in terms of 'country' risk. ${ }^{15}$

Beyond such widespread economic and political recognition of an official and technical nature, Hong Kong's international character comes into play in a variety of additional settings. Over 3,600 foreign companies presently opt to locate their regional headquarters in the territory and it received nearly 22 million tourists in $2004 .{ }^{16}$ Hong Kong has long acted as a magnet for the international media, with close to 100 foreign media currently represented here. ${ }^{17}$ It also serves as a host to hundreds of high-profile NGOs promoting humanitarian and environmental concerns. ${ }^{18}$ Moreover, while the majority of its residents are of Chinese origin, Hong Kong is a highly diverse community from an ethnic/ standpoint. The intimate links with the Chinese diaspora spread throughout the world reinforce the territory's international complexion.

As observed earlier, the HKSAR is a visible player in the global arena, by virtue of being a party to a large number of international agreements and its membership in a wide range

\footnotetext{
${ }^{14}$ See the series of six-monthly reports to the UK Parliament by the Secretary of State for Foreign and Commonwealth Affairs on the Implementation of the Sino-British Joint Declaration on the Question of Hong Kong; most recent report (covering January-June 2005) was submitted in July 2005. Available at http://www.fco.gov.uk/; US-Hong Kong Policy Act reports have been submitted annually by the US Department of State to the US Congress since 1993; the 2004 Report was issued in April 2005. Available at: http://usinfo.state.gov/ ; The Commission of the European Communities has been submitting its Annual Reports on HKSAR to the Council and the European Parliament since 1998; the $7^{\text {th }}$ (2004) Report was issued in July 2005. Available on the website of the Office of the EU in HK and Macao SARS at http://www.delhkg.cec.en.int/en.

${ }^{15}$ See extracts from the Political and Economic Risk Consultancy's 'Report on the Rule of Law in Asia' (based on a survey of expatriate businessmen and multinational companies with regional headquarters) in Albert Wong, 'Rule of Law Best in Asia - but SAR Warned Not to Slip,' The Standard, June 3, 2005.

${ }^{16}$ See Key Statistics provided by InvestHK at http://www.investhk.gov.hk/.

${ }^{17} \mathrm{See}$ http://www.info.gov.hk/hkbi/eng/doc pdf/n11.pdf.

${ }^{18}$ See 'Study on the Third Sector Landscape in Hong Kong,' supra note 5.
} 
of international organisations. Hong Kong is a specially active participant in international economic and trade forums, most significantly the WTO, where it has been hailed as 'an articulate and effective champion of free markets and reduction of trade barriers. ${ }^{19}$ The constructive role performed by Hong Kong's permanent representative to the WTO in presiding over the process that led to the launch of the Doha negotiating round was cited as a vital contribution to the strengthening of multilateral trade channels. ${ }^{20}$ Its scrupulous adherence to the WTO regime and exemplary conduct serving as a 'model' to other members engaged in the liberalisation of foreign trade and investment have also attracted much praise. $^{21}$

At the regional level, Hong Kong's prominent position as a leading commercial, communications, financial, logistics and transportation centre is reflected, inter alia, in multi-dimensional exposure through the APEC forum. As a full and separate member of the organisation, Hong Kong, China (HKC) is represented at all gatherings of the APEC Economic Leaders, as well as the Ministerial and Senior Officials' meetings. It is a full participant in the organisation's seminars and workshops, occasionally hosting such functions, and has contributed meaningfully to the development of trade principles and the formulation of strategies for combating illicit drug trafficking and other customs offences. Hong Kong's powerful private/business sector may also pursue its agenda on the APEC stage through the organisation's Business Advisory Council. ${ }^{22}$

On the face of it, Hong Kong hence seems to possess both the constitutional capacity and international legal tools necessary to reap the full benefits of its special status on the global stage. Yet, the often-encountered tension between theory and practice - or more concretely, between policy potential and government performance - may surface in this intricate political context and bring about a divergence between expectations and reality. Indeed, there is evidence to suggest that the HKSAR 'leadership' has thus far adopted a

\footnotetext{
${ }^{19}$ US State Department, 'Background Note: Hong Kong' at http://www.state.gov. See also EU's welcoming of Hong Kong's "constructive participation" in the WTO, at Europa, 'The EU's Relations with HKSAR' at http://eruopa.eu.int/comm/external relations/hong kong/intro/.

${ }^{20}$ See US Hong Kong Policy Act Report as of 31 March 2002 at http://www.unconsulate.org.hk.

${ }^{21}$ See 'Background Note,' note 19 above.

${ }^{22}$ See Trade and Industry Department, HKSARG, 'APEC and Hong Kong' at htpp://www.tid.gov.hk/print/english/trade relations/tradefora/apec apec hk.html.
} 
rather conservative interpretation of the external affairs powers and responsibilities granted to the territory under the BL. ${ }^{23}$ The purpose of the present paper is to examine this subject from a descriptive, analytical and normative perspective.

\section{Restraint Hinders Progress on the External Front}

The rather narrow path followed by the local bureaucracy in deploying the HKSAR's external relations capabilities is reflected most palpably in the tendency to display a preference for the inter-governmental mode of action. This is evidenced by the fairly large number of post-1997 bilateral agreements concluded by the HKSAR and the dearth of equivalent initiatives of the multilateral variety. The latter have been confined primarily to policy domains where the interplay between domestic and external forces impinges meaningfully on the territory's highly-valued status as an international commercial and financial centre, for example, environmental protection and efforts to combat terrorism.

The 1992 UN Framework Convention on Climate Change (UNFCCC) and its 1997 Protocol have thus been extended to Hong Kong by the Central People's Government (CPG) in April 2003, after consultations with the HKSAR Government in accordance with BL. ${ }^{24}$ In a similar vein, China has announced its decision regarding the application to Hong Kong of the 2001 Convention on Persistent Organic Pollutants (POPs) ${ }^{25}$ as well as the 2003 WHO Framework Convention on Tobacco Control. ${ }^{26}$ To enhance the

\footnotetext{
${ }^{23}$ This was one of the principal findings in a Consultancy Study on Hong Kong's External Relations undertaken by the Institute for China and Global Development (ICGD), the University of Hong Kong, on commission of the Central Policy Unit (CPU) of the HKSAR Government in 2003 (hereafter: ICGD Study); the Study, which thus far has not been officially released, is on file with the author of this article (who was one of the Study's consultants/writers of the report).

${ }^{24}$ See at http://www.unfccc.int/files/essential_background/kyoto_protocol/application/pdf/kpstats.pdf . See also 'HK Accepts UNFCCC, Kyoto Protocol' (30 May 2003)

http://www2.chinadaily.com.cn/en/doc/2003-05/30/content 167202.htm.

${ }^{25}$ The announcement was appended to China's ratification of the Protocol on 13 August 2004. See: http://www.pops.in/documents/signature/sigsttus.html.

${ }^{26}$ See World Health Organisation, 'Updated Status of the WHO Framework Convention on Tobacco Control' (containing a note to the effect that on 11 October 2005 the Government of China informed the
} 
territory's effectiveness in coping with the threat posed by international terrorism, particularly in the post-9/11 era, it has been made a party to the Convention on the Suppression of Terrorist Bombings upon China's ratification of the treaty in $2001 .^{27}$

An extension by the PRC of a key environmental convention to Hong Kong may be a necessary but not sufficient step towards action reflecting the latter's aspirations and capabilities. China is in the early stages of industrialisation and as such enjoys exemptions from certain stringent treaty obligations, notably the need to adhere strictly to mandated targets for reduction of greenhouse gas emissions. By contrast, Hong Kong is an affluent metropolis which should arguably not be content to operate subject to mild constraints of this nature and set goals consistent with those deemed appropriate for the developed world. The measures taken by the PRC thus require positive reinforcement by Hong Kong in the form of a deeper commitment to sustainable development.

Moreover, two major environmental agreements, the Convention on Biological Diversity $(\mathrm{CBD})^{28}$ and its Cartagena Protocol on Biodiversity ${ }^{29}$ have yet to be extended to the territory by China, which is one of the original signatories. It has to be acknowledged that, this notwithstanding, the HKSAR Government has embarked on several initiatives to protect the territory's natural environment. ${ }^{30}$ Be that as it may, the results fall short of meeting the obligations prescribed under the CBD. Of particular relevance in this context is the requirement imposed on contracting parties to formulate long-term national strategies, plans or programmes for conservation and sustainable use of biodiversity.

By the same token, Hong Kong has failed to capitalise on its status as a respected member of key regional multilateral forums in order to help shape the regional and global

Secretary-General of its extension of the Convention to the HKSAR in accordance with the provision of article 153 of the BL), at http://www.who.int/tobacco/framework/countrylist/en/print.html.

${ }^{27}$ See 'China Formally Joins International Convention for Suppression of Terrorist Bombing' at http://english.people.com.cn/200111/14print20011114 84549.html.

${ }^{28}$ Adopted at the 1992 Environmental Summit on Sustainable Development and came into operation in 1993.

${ }^{29}$ The Protocol is designed to control the introduction and transboundary movement of living modified organisms (LMOs).

${ }^{30}$ See HKSAR Government Consultation Paper, Review of Nature Conservation Policy of Hong Kong (2003), at http://www.etwb.gov.hk. 
debates on the environment. For example, it has been suggested that the territory could play a more prominent role in re-activating the various APEC environmental initiatives and action plans aimed at meeting the region's pressing environmental challenges. ${ }^{31}$ Comparable opportunities for enlightened leadership in this policy domain are also provided within the Economic and Social Commission for Asia and the Pacific (ESCAP), where the territory is an Associate Member. In addition, there is considerable scope for further input by Hong Kong into the global debate within the WTO on the strategic issue of the trade/environment relationship. A similar comment may be offered regarding HKSAR's participation (albeit as an observer, yet one of the Dynamic Non-Member Economies [DNMEs]) in the Trade Committee of the OECD, where the territory interacts with OECD representatives on trade related issues, such as the environment, investment and competition.

The inference to be drawn in light of this experience is that even in areas deemed to be economically sensitive, such as environmental protection, the process of converting Hong Kong's external relations potential into a vigorous programme of implementation is evolving in an uneven fashion. The commitment here is deeper and the momentum stronger than elsewhere, but there is a sense of strategic selectivity, which may be grounded in political logic, and the pace apparently varies according to the dynamics of the Hong Kong-China relationship. Given the prevailing constraints and the potentially costly implications of a more adventurous policy course, the pattern witnessed is not entirely inconsistent with what one might typically expect in such circumstances, but the picture that emerges suggests a tendency to err invariably on the side of caution and not to take proper advantage of opportunities for legitimate international role expansion where the risks are distinctly modest.

The terrorist challenge is also not addressed in an unambiguously resolute manner. Generally, the territory is perceived as a faithful participant in the "war against

\footnotetext{
${ }^{31}$ See ICGD Study, note 23 above.
} 
terrorism ${ }^{, 32}$ and has keenly ${ }^{33}$ enacted legislation to give effect to United Nations Security Council Resolutions (UNSCR) concerning terrorism and terrorist financing. ${ }^{34}$ Hong Kong has been further commended for the leading role it plays, as a member of the FAFT, ${ }^{35}$ in seeking ways to stem the flow of funds to terrorist groups, a pattern possibly partly attributable to local policy makers' concern over 'possible abuse of [its] status as an international city by those who wish to launder illicit money through [its] financial system. ${ }^{36}$ Special praise has also been heaped on Hong Kong for its active participation in the US Container Security Initiative (CSI) programme, aimed at preventing weapons of mass destruction from entering the United States. ${ }^{37}$

In contrast, two major anti-terrorism conventions,${ }^{38}$ the 1999 Convention for the Suppression of Financial Terrorism and the 1980 Convention on Physical Protection of Nuclear Material are still awaiting application to the territory. On a regional level, although Hong Kong is one of the founding members of the Asia/Pacific Group on Money Laundering (APG), it has stopped short of extending its involvement to 'TrackII ${ }^{39}$ regional multilateral institutions concerned with so-called "non-traditional security"

\footnotetext{
${ }^{32}$ See US-Hong Kong Policy Act Report of 1 April 2005 [US-HK Policy Report 2004], at http://www.state.gov/p/eap/r/s/rpt/44543.htm.

${ }^{33}$ In fact, attracting criticism of the manner in which such legislative acts were passed. See Press Release by Amnesty International Hong Kong addressed to the Chief Executive and members of the Legislative Council dated 21 October 2002, expressing 'concerns and regrets' over the rushing through of the United Nations (Anti-Terrorism Measures) Ordinance, at http://www.amnesty.org.hk/press/anti_terror_hk.htm. ${ }^{34}$ Most notably, the United Nations (Anti-Terrorism Measures) Ordinance - enacted in July 2002 to implement [the mandatory elements of] UNSCR 1373 and [the most pressing] Special Recommendations of the Financial Action Task Force on Money Laundering [FATF] - and the UN (Anti-Terrorism Measures) (Amendment) Ordinance, passed in July - to give full effect to UNSCR 1373 and the FATF Special Recommendations.

${ }^{35}$ See US-HK Policy Report 2004.

${ }^{36}$ See presentation by Hong Kong's Director of Public Prosecutions, Grenville Cross, SC on "Cooperation in the Combat of Terrorism and Terrorist Finance - An Asian Perspective" (August 2003), available online at http://www.iap.nl.com/speeches_annual_conference_2003_washington/.

${ }^{37}$ See US-HK Policy Report 2004. It is interesting to note that notwithstanding sovereignty issues involved in basing US government officials on Chinese territory, Hong Kong has been given a "free hand" to conclude this cooperation arrangement with the US.

${ }^{38}$ See list of the twelve major multilateral conventions and protocols related to states' responsibilities for combating terrorism at http://www.undoc.org/undoc/terrorism conventions.htm. Note also the recent addition to the list of the International Treaty for the Suppression of Acts of Nuclear Terrorism, adopted by the UN General Assembly on 13 April 2005, available at http://untreaty.un.org/English/Terrorism/English_18_15.pdf.

${ }^{39}$ Track II has been described as "unofficial, informal interactions between members of advisory groups or nations which aim to develop strategies, influence public opinion, and organised human and material resources in ways which might help to resolve their conflict." See Joseph V. Montville, "The Arrow and
} 
issues that cover transnational crime, including illegal migration, drugs and piracy. Again, the picture that emerges is indicative of uneven strategic navigation, featuring inertia in areas normally accorded close policy attention because of their implications for the material well-being of an exceptionally open and externally dependent economy.

That said, inaction may at times be the product of Hong Kong-centred cost-benefit analysis and should not be viewed invariably as a reflection of self-imposed restraint within the 'One Country, Two Systems' framework or barriers placed by the PCG. Indeed, it might be considered as a sign of assertiveness in that international treaties, to which China is a party, are not readily embraced because of concerns about the economic consequences of complying strictly with their provisions. Typical in this regard is the caution displayed with respect to the extension to the territory of the 1951 Convention Relating to the Status of Refugees, along with its 1967 Protocol. Notwithstanding the 'Concluding Observations' issued by the UN Committee on Economic and Cultural Rights in May 2005, ${ }^{40}$ no concrete steps have been taken to remedy the situation. ${ }^{41}$

The lack of treaty-based international obligations, an otherwise relevant factor in assessing the domestic policy manoeuvring, should not justify the apparent reluctance ${ }^{42}$ on the part of the Hong Kong judges to apply rules grounded in customary international law (which form a part of the Hong Kong legal system as a 'derivative' of the Common

the Olive Branch: A Case for Track-Two Diplomacy," in John W. Macdonald and Dian B. Bendahmane, eds., Conflict Resolution: Track Two Diplomacy (Washington, DC: Institute for Multi-Track Diplomacy, 1995); The term has been applied to policy meetings or organisations whose members are normally comprised of academics, non-governmental organisations, economic or business interests, and [lower-level] government officials. One of the more visible Track-II groups in Asia is the Council for Security Cooperation in the Asia-Pacific (CSCAP). For Track-II activities in Asia, see Brian Job, "Track 2 Diplomacy: Ideational Contribution to the Evolving Asia Security Order," in Muthiah Alagappa, ed., Asian Security Order: Instrumental and Normative Features (Stanford, CA: Stanford University Press, 2003).

${ }^{40}$ See Committee on Economic, Social and Cultural Rights, $34^{\text {th }}$ Session (25 April-13 May 2005), 'Concluding Observations of the Committee on Economic, Social and Cultural Rights: China' at http://www.unhchr.ch/tbs/doc.nsf/.

${ }^{\frac{}{41}}$ See Roda Mushkat and Kelley Loper, 'Refugee Protection in the Asia and Pacific Region: An External Study of Refugee Law \& Practice in Hong Kong' (prepared for UNHCR Sub-Office Hong Kong, 15 February 2005; on file with the author). See also Matthew Lee, "'Flood" Fear on Asylum Seekers. Government has no plans to change its stance on refugees, despite urging by United Nations,' The Standard, June 22, 2005, A11.

${ }^{42}$ For instances reflecting such reluctance see Roda Mushkat, "International Law in HKSAR Courts" (1998) 28 California Western International Law Journal, 353-377. 
Law) and other, 'softer' sources of international law. ${ }^{43}$ Hong Kong courts are not constitutionally or legally impeded, and are fully competent to decide questions of international law that arise in the course of legal proceedings over which they exercise jurisdiction in accordance with the domestic legal system. Specifically, subject to the overarching limitation resulting from the exclusion of 'defence and foreign affairs' from the territory's control, the HKSAR courts are required to 'adjudicate cases in accordance with the laws applicable in the Region' (BL 84), including, when applicable, international law. Indeed, judges are not merely authorised to apply international law, but they may also incur international responsibility for its misapplication. The duty thus imposed extends to judicially reviewing executive acts for conformity with the territory's international legal obligations and to interpreting HKSAR law consistent with international law.

The HKSAR judiciary is highly regarded in the Asian Pacific region for its independence, integrity, professionalism, the breadth/depth of its jurisprudence, and the respect shown generally to international judicial decisions. It may also be contended that such a reputation has been further enhanced after the resumption of Chinese sovereignty, given the unique composition of the HKSAR Court of Final Appeal (which includes distinguished judges from other common law jurisdictions). ${ }^{44}$ Concerns have nonetheless been expressed over incidents that gave rise to perceptions, whose validity cannot be categorically dismissed, that the power of final adjudication stems in some crucial respects from an institutional source other than the Court of Final Appeal. ${ }^{45}$

In the executive arena, albeit not without judicial ramifications, similar caution permeates attitudes towards the newly formed International Criminal Court (ICC) and the possibility of establishing Hong Kong as one of its principal bases. As a prominent local barrister

\footnotetext{
${ }^{43}$ For example, the Rio Declaration on Environment and Development, Agenda 21, the Syracuse Principles on the Limitation and Derogation of Provisions of the International Covenant on Civil and Political Rights, the Johannesburg Principles on National Security, Freedom of Expression and Access to Information.

${ }^{44}$ The 'utmost respect for the Hong Kong judiciary' is exemplified by the Lord Chancellor's continuing practice of sending three judges from the House of Lords to sit on Hong Kong's Court of Final Appeal. See the Six-Monthly Report on Hong Kong, July 2002-December 2002, para. 43.

${ }^{45}$ See for further discussion Miron Mushkat and Roda Mushkat, 'The Political Economy of the Constitutional Conflict in Hong Kong' (2004) 11 Tilburg Foreign Law Review 756, 767-768.
} 
has pointed out, the ICC Statute 'provides that countries which have not signed or ratified the treaty can still conclude cooperation agreements with the Court by which they agree to give the court assistance. ${ }^{46}$ While the PRC has neither signed nor ratified the ICC treaty, in a July 2002 statement to the Security Council, a representative of China remarked that '[a]lthough China is not yet a State Party to the International Criminal Court, we support the independence, impartiality, and competence that the ICC enjoys universally. We have continued to actively participate in the establishment of the ICC and will continue to follow closely its operation. ${ }^{47}$ There is thus no obvious political reason for Hong Kong not to adopt a more positive posture towards the institution. To the extent that high risk aversion by a fundamentally conservative bureaucracy underlies the inward-looking stance on that front, the territory may incur an opportunity cost in that a policy of constructive engagement could have reinforced its claims to 'Asia World City' status by virtue of an unambiguous commitment to legal excellence, in the international sense of the term.

\section{Towards a More Meaningful External Architecture}

As the examination undertaken in the preceding section of the paper illustrates, post-1997 Hong Kong may have fallen short of fulfilling the potential for effective external action inherent in the international legal façade erected by the PRC and the United Kingdom. This manifests itself in key strategic domains and across-the-(policy)-board. The current configuration may be portrayed as sub-optimal in this respect and a more satisfactory pattern should arguably be pursued. From a normative perspective, it is not inappropriate to suggest a blueprint broadly consistent with the territory's status as an 'international legal person ${ }^{48}$ and the emerging notion of 'global citizenship. ${ }^{49}$

\footnotetext{
${ }^{46}$ Paul Harris, 'Hong Kong Can Play a Role in Global Justice,' South China Morning Post, 30 October 2001.

${ }^{47}$ Quoted from the website of the Coalition for the International Criminal Court in www.iccnow.org. Further evidence of the PRC's basic support for the court can also be found in a Statement by Mr. Guan Jian, Representative of China, to the $6^{\text {th }}$ Committee of the $57^{\text {th }}$ session of the UN General Assembly, on Agenda Item 158: "Establishment of the International Criminal Court."

${ }^{48}$ See Roda Mushkat, One Country, Two International Legal Personalities, note 1 above. For a general discussion of the concept of "international legal personality," see: Janne Elisabeth Nijman, The Concept of
} 
In passing, it should be noted that such a blueprint dovetails with the general imperative to convert the 'Asia World City' formula, which looms large on the Hong Kong public agenda, but is seldom infused with any substance, into a macro vision to drive the territory's legitimate international aspirations (without, of course, encroaching on China's sovereignty). This may involve taking steps extending beyond the traditional boundaries of economics and trade, and exercising regional leadership on the cultural, environmental, humanitarian, legal, political and social fronts in a distinctly 'international' fashion.

As pointed out earlier, the territory is subject to a wide range of international legal obligations grounded both in treaties and 'soft law." ${ }^{50}$ Most palpable commitments stemming from the latter source include the promotion of sustainable development ${ }^{51}-$ at the national, regional and global level - and the effective prevention of and appropriate response to disasters and major public health threats, within the broad framework of 'human security' enhancement. ${ }^{52}$ Given the high standard of living enjoyed by its residents, as well as the sophisticated physical and institutional infrastructure underpinning economic activity in Hong Kong, the territory can be said to carry 'industrialized country-type' responsibilities assumed by participants in the 'global

International Legal Personality: An Inquiry into the History and Theory of International Law (The Hague: T.M. Asser Press, 2004).

${ }^{49}$ See generally: April Carter, The Political Theory of Global Citizenship (London: Routledge, 2001).

${ }^{50}$ See note 41 above.

${ }^{51}$ This involves adherence to well-established principles such as the duty to ensure sustainable use of natural resources; the principle of equity and the eradication of poverty; the principle of precautionary approach to human health, natural resources and ecosystems; the principle of public participation and access to information and justice; the principle of good governance; and the principle of integration and interrelationship, in particular in relation to human rights and social, economic and environmental objectives. See International Law Association, '2002 New Delhi Declaration on the Principles of International Law Related to Sustainable Development' in Report of the Seventieth Conference, New Delhi (London: ILA, 2002); Marie-Claire Cordonier Segger and Ashfaq Khalfan, Sustainable Development Law: Principles, Practices and Prospects (Oxford: Oxford University Press, 2004).

${ }^{52}$ See UN Secretary-General High-Level Panel on Threats, Challenges and Change, A More Secure World: Our Shared Responsibility (United Nations, 2004), at p 2. 
partnership for development,' as provided in the United Nation Millennium Declaration ${ }^{53}$ and the Johannesburg Plan of Implementation. ${ }^{54}$

Specifically, Hong Kong is expected to take concrete steps to adopt and execute in a comprehensive fashion its own domestic socio-economic strategies in order to achieve internationally agreed-upon development objectives such as the UN's Millennium Development Goals (MDGs). ${ }^{55}$ By the same token, it needs to support tangibly efforts by poorer countries to embrace and implement in a satisfactory manner policies conducive to socio-economic progress - inter alia, through constructive development assistance schemes. ${ }^{56}$ In addition, it should act to facilitate the contribution of non-governmental organisations, civil society, the private sector and other relevant stakeholders towards the improvement in the quality of the domestic socio-economic environment and the global system in which it is embedded.

Being an integral part, even if a distinct one for administrative purposes, of the world's 'largest [and most dynamic] developing country' imposes a particularly heavy burden in that context. This dimension of the picture is highlighted in a recent Greenpeace report ${ }^{57}$ which focuses on the negative externalities generated as a result of China's rampant economic expansion, especially its disruptive ecological consequences. The corollary is that Hong Kong has to go to great lengths in pursuing the environmental protection component of the goal of sustainable development. With reference to the challenges posed by the mainland in this respect, it behoves the territory to intensify its cross-border cooperation and include in the policy repertoire significant measures to alleviate transfrontier pollution, as well as serious initiatives regarding clean energy and climate

\footnotetext{
${ }^{53}$ General Assembly Resolution 55/2 (8 September 2000), at http://www.un.org/millennium/declaration/ares552e.htm.

${ }^{54}$ UN Report of the World Summit on Sustainable Development, Johannesburg, South Africa, 26 August-4 September 2002 (A/CONF.199/20), at http://www.johnnesburgsummit.org/html/documents/summit_dox/131302_wssd_report_reissued.pdf.

${ }^{55}$ See at http://www.un.org/millenniumgoals/.

${ }^{56}$ Under para. 79 of the WSSD Plan of Implementation (note 51 above), governments operating in developed economy settings should aim to contribute $0.7 \%$ of GNP as overseas development aid to developing countries.

${ }^{57}$ Greenpeace, Annual Report 2005, available at http://www.greenpeace.org/international/press/reports/annual-report-2005.
} 
change. It also follows that Hong Kong must step up its policing and enforcement efforts to eradicate China-centred illegal trade in endangered species. ${ }^{58}$

The lack of transparency displayed by the PRC following the outbreak of the Severe Acute Respiratory Syndrome (SARS) is indicative of the challenges faced on the health front and underlines the need for broadly proactive strategies in this increasingly problematic (given the great risks posed by the Avian influenza ${ }^{59}$ ) domain. Indeed, consistent with the newly revised International Health Regulations (IHR) of the World Health Organisation (WHO), ${ }^{60}$ the territory should establish and maintain core surveillance and response capabilities required to confront the threats stemming from the spread of infectious diseases, both of the familiar and emergent varieties. This ought to encompass detection mechanisms, assessment procedures, reporting structures, verification tools, and multilevel decision-making and implementation vehicles. ${ }^{61}$

Such obligations are not confined to the building of an appropriate domestic policy foundation. According to the revised IHR, ${ }^{62}$ they also call for close collaboration with other relevant external parties in every stage of this complex process - which has administrative, legal, logistic, political, scientific/technical and social dimensions. Hong Kong's economic vigour and institutional competencies (recent health crises have brought to the fore the comparative advantages it enjoys due to its open system, largely unhindered information flows, credible rule of law and high professional standards)

\footnotetext{
${ }^{58}$ Hong Kong serves as the global hub for the transport of sea cucumber, dried seahorse, abalone and shark's fin, which are in great demand in mainland China. See Simon Parry, 'Cargoes of Cruelty,' South China Morning Post, 8 June 2005, at A14.

${ }^{59}$ 'The appearance of such a virus in today's globalised world has raised the spectre of a pandemic of equal or greater ferocity than the 1918-1919 influenza pandemic, which killed millions world wide.' See David P. Fidler, 'The Continuing Global Spread of Avian Influenza A (H5N1) and Its Implications for International Law' ASIL Insight, November 7, 2005 (and references therein).

${ }^{60}$ See Revision of the International Health Regulations, $58^{\text {th }}$ World Health Assembly, WHA58.3, Agenda item 13.1 (23 May 2005), available at http://www.who.int/csr/ihr/en/. The revised IHR will enter into force in May 2007. Interestingly, although it has yet to become formally applicable to Hong Kong, the Government has relied one revised IHR as the 'legal basis' for disease control in the territory. See HKSAR Health, Welfare and Food Bureau, Hong Kong's Preparedness for Influenza Pandemic - Prevention and Protection (2005), available at http://www.chp.gov.hk.

${ }^{61} \mathrm{Ibid}$., IHR, Articles 5.1 and 13.1 and Annex 1.

${ }^{62}$ Ibid., IHR, Article 44.
} 
inevitably require the territory to play a regional leadership role in combating health hazards and discharge its general responsibilities in a manner befitting a 'global citizen.'

Those responsibilities clearly extend to providing humanitarian assistance to areas seriously affected by major natural disasters such as the recent Indian Ocean tsunami. ${ }^{63}$ While Hong Kong's contribution, as a single-city donation (HK\$ 700 million) and on a per-capita basis (HK\$ 100) has exceeded that of other equivalent donors, ${ }^{64}$ this particular spontaneous display of compassion at the grass-roots level, mirrored in public opinion surveys at a number of junctures, ${ }^{65}$ has not found a coherent expression, let alone of the formal type, in government policy. The latter continues to evolve in an ad hoc fashion and lacks a comprehensive framework for addressing the consequences of catastrophes in an efficient and equitable manner.

Hong Kong is a special administrative region of another country and its foreign affairs are the prerogative of the PRC. Nevertheless, its unique status, coupled with superior capabilities, implies greater international commitments than might be expected in the case of affluent metropolises in general. It is little known that the government set up in 1994 a Disaster Relief Fund (DRF), which supports local NGOs in their endeavours to offer disaster relief elsewhere. There is ample scope to convert this narrow-based organisational instrument into a wider channel for overseas development assistance, yet no significant official initiatives have been taken in this respect. ${ }^{66}$

It is obvious that any progress towards fulfilling the global citizen vision hinges on parallel movement directed at fostering a supportive environment for civil society organisations, which need to be empowered to play a more active role regionally and internationally. As matters stand, they are inadequately equipped, both in terms of resources and mindset, to embark on such a course, a pattern that diverges from that

\footnotetext{
${ }^{63}$ See note 49 above referring to the broadening of 'human security' to include the duty to effectively protect, alert and provide relief to population threatened by natural disasters.

${ }^{64}$ See Anthony Cheung, 'Global City? Look Beyond China, Hong Kong' South China Morning Post, 24 January 2005.

${ }^{65}$ See surveys conducted and relied upon in the ICGD Study, note 23 above, appendix 3.2.

${ }^{66}$ See ICGD Study, ibid, at 47.
} 
witnessed in other jurisdictions with similar socio-economic characteristics. The prevailing constraints and the attitudinal consequences thereof are duly reflected in current organisational positioning and views communicated in personal interviews. ${ }^{67}$

The corollary is that the government must adopt a more constructive posture vis-à-vis NGOs fundamentally suited for this challenging task. The latter need explicit encouragement and concrete assistance to acquire the necessary international skills and external exposure. By the same token, it should take tangible steps to attract international bodies and NGOs to establish presence in Hong Kong. As a matter of strategic principle, and as a reaffirmation of the resolutions promulgated at the 2005 World Summit, the government ought also to commit itself, formally and appropriately, to enhancing the contribution of NGOs and civil society (as well as the private sector and other relevant stakeholders) to the promotion of the 'global partnership for development. ${ }^{, 68}$

Effective functioning as a global citizen, and maintenance of a viable network of external relations, depend on less mainstream factors as well. Specifically, a full recognition of one's own culture and a systematic acquisition of knowledge about other cultures is called for. This is attested to by the proliferation of international conventions aimed at the protection of cultural heritage and diversity ${ }^{69}$ and, to varying degrees, by the practice of national and sub-national entities. ${ }^{70}$

Hong Kong has the potential to serve as a cultural 'bridge' between East and West. Although widely regarded as a symbol of globalisation, ${ }^{71}$ it remains in many respects a quintessentially Chinese society. At the same time, its colonial legacy and position as an

\footnotetext{
${ }^{67}$ See ibid, at 51.

${ }^{68}$ See General Assembly Resolution 60/1, '2005 World Summit Outcome' (24 October 2005), Section $22(\mathrm{e})$.

${ }^{69}$ The latest addition to key conventions for the protection of the world's cultural heritage (such as UNESCO Convention Concerning the Protection of the World Cultural and Natural Heritage 1972 and UNESCO Convention for the Safeguarding of the Intangible Cultural Heritage 2003) is UNESCO Convention on the Protection and Promotion of the Diversity of Cultural Expressions, adopted on 20 October 2005.

${ }^{70}$ As evidenced, inter alia, by the large number of parties to the major conventions cited ibid. For the relevant data see: $\mathrm{http}: / /$ portal.unesco.org/la/convention/.

${ }^{71}$ See David R Meyer, Hong Kong as a Global Metropolis (Cambridge: Cambridge University Press, 2000).
} 
international centre of commerce and finance sensitise it to Western forms of artistic expression. ${ }^{72}$ The territory is thus uniquely qualified to act as a cultural hub and should intensify its efforts to invest in 'cultural capital' in its various forms ${ }^{73}$ (including the development of 'cultural tourism').

It needs to be emphasised that, as reflected in applicable international legal instruments, the protection of cultural heritage and measures geared towards its enhancement are not viewed as merely supporting the ends of cultural capital formation and dissemination. They are also considered as invaluable means of promoting international harmony by increasing mutual understanding across cultures and fostering a climate of tolerance among peoples. ${ }^{74}$ For this reason, international cultural relations have become an integral part of modern diplomacy and the management of external relations.

About $1 \%$ of the government budget is devoted to culture. This is not an insignificant figure by regional, and even international, standards. Yet, it is debatable whether the resources are deployed creatively and within a framework of strategic priorities. Various projects are embarked upon by different segments of the bureaucracy in an ad hoc fashion and without being inspired by a deep insight into the international underpinnings of cultural capital formation. Hong Kong does not have a coherent cultural exchange policy and its international cultural identity is said to be languishing. Paradoxically, the exportation of culture lags substantially behind its importation. ${ }^{75}$ Such deficiencies merit careful policy attention. ${ }^{76}$

\footnotetext{
${ }^{72}$ See Grant Evans and Siumi Maria Tam, eds., Hong Kong: The Anthropology of a Chinese Metropolis (London: Curzon Press, 1997).

${ }^{73}$ See generally: David Throsby, 'Cultural Capital' (1999) 23 Journal of Cultural Economics, 3-12

${ }^{74}$ See for example: Preamble to UNESCO Convention for the Safeguarding of the Intangible Cultural Heritage 2003.

${ }^{75}$ For a comprehensive analysis of these issues, see Culture and Heritage Commission, Policy Recommendation Report (Hong Kong, 31 March 2003), available at http://www.hab.gov.hk/file manager/en/documents/policy_responsibilities/CHC-

PolicyRecommendationReport_E.pdf.

${ }^{76}$ As acknowledged in 'Government Response' [to the Policy Recommendation Report, ibid] - available at http://www.hab.gov.hk/file manager/en/documents/policy responsibilities/arts culture recreation_and sp ort/GovResCHCReport.pdf. - and in the Chief Executive's Policy Address 2005, sections 83-89, available at http://www.policyaddress.gov.hk/2005.
} 
There is less ambiguity, or perhaps no ambiguity at all, with respect to the commitment to the principles of legal transparency and accountability. Indeed, this is a critical area where Hong Kong may act as a beacon to most of its neighbours. The vitality of the local common law system has prompted experienced observers ${ }^{77}$ to suggest that the territory has the necessary attributes to evolve into a leading regional/international dispute resolution centre. Strong emphasis has been placed in this context on the government's determination to uphold the rule of law, independence of the judiciary, distinctly low level of corruption, high degree of openness and visibility, efficient process, predictability of outcome, enforceability of judgments, abundance of professional expertise and excellent physical infrastructure (including a wide range of sophisticated communications and transport channels).

By the same token, Hong Kong's legal capabilities qualify it for a regional leadership role on the corporate governance front. The edifice the territory has established in this increasingly focal area falls somewhat short of best international practices (structural gaps receiving attention include inadequate protection for minority investors, unavailability of class actions, overly liberal enforcement and the absence of a super regulatory body possessing substantial investigative powers). ${ }^{78}$ Nevertheless, Hong Kong is comfortably ahead of other economies in the region (Australia, New Zealand and Singapore being a possible exception to the norm) in terms of the depth of its corporate governance regime. ${ }^{79}$ It already provides a platform for ongoing exchanges on the subject and could broaden its involvement further. ${ }^{80}$

To realise its potential as a positive catalyst for relevant legal/institutional reforms beyond its borders, Hong Kong needs to adhere unambiguously to international human

\footnotetext{
${ }^{77}$ As documented in ICGD Study, note 23 above, at 69.

${ }^{78}$ See ICGD Study, at 70.

${ }^{79}$ See OECD 2003 White Paper on Corporate Governance in Asia and Asian Roundtables on Corporate Governance, most recently in September 2005, offering the '2005 Stock Taking of Corporate Governance Related Developments in Asian Roundtable Economies,' available at http://www.oecd.org/topic; See also Jamie Allen, 'The Corporate Governance Landscape in Asia' (1 December 2005), available at http://www.acga-asia.org/public/files/ACGA_Presentation_SPARX_Roundtable_Dec05.pdf (containing a 'country ranking: CG Watch').

${ }^{80}$ See ICGD Study, at 70.
} 
rights applicable to the territory and pursue unwaveringly the protection of fundamental rights and freedoms guaranteed under both the Sino-British Joint Declaration and the Basic Law. As reflected in key international 'monitoring' reports, its respect for human rights (as well as the 'development of democratic institutions') is regarded as a crucial indicator of Hong Kong's autonomy and its status as a free and open society. Overall, the tone of such reports has been consistently favourable. ${ }^{81}$

Yet, a number of concerns have been expressed in the reports and other authoritative assessments, pertaining inter alia to the failure of present anti-discrimination legislation to cover discrimination on the basis of race, sexual orientation and age; the lack of effective protection from abuse for foreign domestic helpers; and the absence of a clear asylum policy (and the non extension to Hong Kong of the 1951 Convention Relating to the Status of Refugees and the 1967 Protocol thereto). ${ }^{82}$ Previous reports highlighted possible threats to the freedom of assembly and association, the lack of domestic legislation prohibiting racial discrimination in the private sector, potential encroachments on the freedom of the press (media self-censorship), arguably draconian proposed national security legislation (shelved but not buried) and the halting progress towards genuinely representative government. ${ }^{83}$ The government has attempted to respond to some of these concerns, albeit at times unevenly and not always in practical terms. ${ }^{84}$ It is legitimate to assert that a more concerted effort to address such and other policy gaps identified in this section is required, if the territory is to move onto the regional/global stage in a manner consistent with expectations embedded in relevant international agreements and its own capabilities.

\footnotetext{
${ }^{81}$ See reports cited in note 14 above.

${ }^{82}$ See 'Concluding Observations of the Committee on Economic, Social and Cultural Rights' (13/05/2005), note 38 above.

${ }^{83}$ See reports cited in note 14 above.

${ }^{84}$ See ICGD Study, at 72-3. It may be noted in this connection that Hong Kong's Second Report with respect to its obligations under the International Covenant on Civil and Political Rights, submitted in early 2005 (available at http://www.hab.gov.hk/en/policy responsibilities/the rights of the individuals/) is yet to be reviewed by the UN Committee on Civil and Political Rights.
} 


\section{$\underline{\text { Institutional Dynamics }}$}

The survey and analysis undertaken in this paper lead to the conclusion that Hong Kong enjoys, by virtue of the unique international legal arrangements governing its position as a Special Administrative Region of the PRC, a considerable scope for conducting its external affairs in a discretionary and meaningful fashion. Indeed, it can be argued that it is incumbent upon the territory to act in accordance with the powers granted to it and its own formidable endowments. However, as demonstrated here, the current configuration does not fully conform to the prescriptive model. The question thus arises whether it is possible to account systematically for the divergence between prescription and execution.

As indicated in the main body of the text on a number of occasions, Hong Kong restraint may be attributed partly to narrow self-interest. ${ }^{85}$ The adjective 'narrow' is employed in this context in order to suggest that issue-specific considerations may at times dominate broader factors, culminating in decisions that may be grounded in sound tactical logic but may not necessarily generate strategic advantages for the territory as a whole (i.e., longterm/community-wide benefits may be sacrificed because of the desire to sustain shortterm/selective progress). Such 'myopic' responses are common and by no means confined to Hong Kong. ${ }^{86}$

An explanation with more structural underpinnings might centre on the nature of the bureaucratic process. Approaching the picture from such an angle is also interesting from an international legal perspective for it brings into focus the often encountered gap

\footnotetext{
${ }^{85}$ See also Ian Scott, ed., Institutional Change and Political Transition in Hong Kong (Basingstoke: Palgrave Macmillan, 1998); Sonny H Lo, Governing Hong Kong (New York: Nova Science, 2002); John P Burns, Government Capacity and the Hong Kong Civil Service (Hong Kong: Oxford University Press, 2005); Ian Scott, Public Administration in Hong Kong: Regime Change and its Impact on the Public Sector (Singapore: Marshall Cavendish, 2005); Miron Mushkat and Roda Mushkat, 'The Political Economy of Governance and public Trust: The Promise of Autonomy and Post-1997 Hong Kong Inertia,' International Quarterly for Asian Studies (forthcoming).

${ }^{86}$ See Miron Mushkat and Roda Mushkat, 'The Political Economy of Constitutional Reform in an Externally-constrained Environment: China's Shadow Over Hong Kong and Strategies to Minimise It' (2003) 30 Journal of Malaysian and Comparative Law, 15-36; Miron Mushkat and Roda Mushkat, 'Conversationalism, Constitutional Economics and Bicameralism: Strategies for Political Reform in Hong Kong' (2005) 13 Asian Journal of Political Science, 22-49.
} 
between prescriptions rooted in international law and institutional realities. ${ }^{87}$ The point is that the pre-1997 Hong Kong bureaucracy, in many respects inward-looking and static in its orientation, was neither adequately equipped nor sufficiently prepared to make the quantum leap into the post-1997 era and confront effectively the external challenges bound to emerge following the resumption of sovereignty by the PRC within the 'One Country, Two Systems' framework. This observation remains valid today. ${ }^{88}$

Post-1997 reforms have exacerbated the problem to a certain extent. Their official aim is to pave the way to representative government. Yet, because of their piecemeal character, they have resulted in substantial institutional fragmentation and even a degree of policy paralysis. According to a leading social scientist, the political system has become 'disarticulated.' Specifically, given that the set-up amounts to 'neither parliamentary fish nor presidential fowl, the executive, the bureaucracy and the legislature (which is divided within itself) each pursue their own agendas, punctuated by occasional skirmishes on the boundaries of their domains and by subterranean campaigns to extend their jurisdictions. $^{, 89}$

Moreover, building external bridges and pursuing the 'global citizen' vision may not be top priorities for the local bureaucracy. ${ }^{90}$ It is legitimate to contend that those who presently occupy its high layers display a 'northern'/mainland orientation rather than a cosmopolitan outlook. Their principal objective seems to be the maximisation of Chinarelated advantages and the minimisation of China-related risks. To pursue a bolder and more multi-dimensional strategy might be perceived as tantamount to opening a Pandora box. $^{91}$

\footnotetext{
${ }^{87}$ See Miron Mushkat and Roda Mushkat, 'The Political Economy of International Legal Compliance: Pre1997 Predictions and Post-1997 Realities in Hong Kong' (2004) 10 U.C. Davis Journal of International Law and Policy 501-518; Miron Mushkat and Roda Mushkat, 'International Law and Game Theory: A Marriage of Convenience or Strange Bedfellows?' (2005) 2 New Zealand Yearbook of International Law, 101-126.

${ }^{88}$ See John P Burns, note 81 above; Ian Scott, note 81 above.

${ }^{89}$ Ian Scott, 'The Disarticulation of Hong Kong's Post-Handover Political System' (2000) 43 China Journal, 29, 29.

${ }^{90}$ See ICGD Study.

${ }^{91}$ See Sonny H Lo, note 81 above.
} 
It has been further argued, quite compellingly but somewhat controversially, that the tension between quasi-authoritarian and democratic forces (the former restraining and the latter challenging) has led to a 'crisis of legitimacy' and has triggered a process of 'political decay' in post-1997 Hong Kong. The origins of the former can be traced to rising democratic aspirations in a complex urban environment, where the emerging social structure is skewed towards the middle class against the backdrop of selective infringements on local autonomy by China (and occasionally by the pre-1997 government, in the twilight of colonial rule). The lack of sensitivity apparently exhibited vis-à-vis these aspirations is thought to be a source of widespread cynicism that manifest itself directly and indirectly regarding government institutions and the political establishment presiding over them. ${ }^{92}$

Political decay is another potential symptom of "reverse democratisation." ${ }^{93}$ It seems to take the form of a tangible deterioration in government performance as evidenced, inter alia, by the adoption of a Third World-style personal rule at top echelons of the executive branch, reliance on patron-client networks, politicisation of the judiciary, cavalier attitude towards freedoms in general and civil liberties in particular, indifference to public opinion, poor response to demands emanating from the grass roots, erratic policy formulation and implementation, symbolic manipulation, and propensity to play one segment of the community against another. ${ }^{94}$

This rather harsh liberal critique may not accord fully with prevailing post-1997 Hong Kong institutional realities. It is debatable whether the territory is experiencing reverse democratisation in the strict sense of the term, a serious crisis of legitimacy and accelerating political decay. Nevertheless, it highlights the conflicting forces at work and the selective deterioration in the social climate. Progressive strategic initiatives are inevitably regarded as the product of democratic influences and thus not sufficiently aligned with Chinese interests. In this climate, one may expect the executive arm of the Hong Kong Government to move cautiously on the external front, the considerable

\footnotetext{
${ }^{92} \mathrm{Ibid}$.

${ }^{93} \mathrm{Ibid}$.

${ }^{94}$ Ibid.
} 
positive inertia and significant countervailing pressures notwithstanding. The proverbial 'half full-half empty'glass may not fill up for some time. 